DE

M E D I C I N A

T R O P I C A L

$\mathrm{DE}$

SÃO PAULO

JOURNAL OF THE SÃO PAULO INSTITUTE OF TROPICAL MEDICINE
Universidade Federal de Uberlândia, Instituto de Ciências Biomédicas, Minas Gerais, Brazil

Correspondence to: Márcia Cristina Cury Universidade Federal de Uberlândia, Instituto de Ciências Biológicas, Laboratório de Parasitologia, Av. Pará, 1720, Bloco 4C, CEP 38400-902, Uberlândia, MG, Brazil Tel: +55 34 3218-2198, +55 34 3218-2333

E-mail: cury@umuarama.ufu.br

Received: 30 November 2016

Accepted: 31 January 2018

\section{Distribution and risk factors of Ascarididae and other geohelminths in the soil of Uberlandia, Minas Gerais, Brazil}

Kelem Cristina Pereira Mota, Daliane Faria Grama, Natália M. Nasser Fava, Letícia Pereira Úngari, Elaine Silva Marques Faria, Márcia Cristina Cury

\section{ABSTRACT}

Among the geohelminths, parasites from the Ascarididae family have a significant role in the human and animal health. This research aims to determine the prevalence of Ascarididae species in the soil in different areas located in a city of Minas Gerais State, Brazil (South America). The study was developed in squares, parks, sports clubs, orchards and municipal children's schools. Samples of sand/soil/grass were collected from January to August 2014. The optical microscope screening was performed through formal-ether and spontaneous sedimentation techniques. Out of the 183 collected samples, eight $(4.4 \%)$ belonged to parks, $16(8.7 \%)$ to sports clubs, $76(41.5 \%)$ to squares, $23(12.6 \%)$ to orchards, and $60(32.8 \%)$ to schools. Out of the total, $28(15.3 \%)$ contained Ascarididae eggs. Higher levels of positivity were demonstrated in the raining season $(25.0 \%)$, in samples collected in the southern region of the town $(25.1 \%)$, on ground soils $(27.3 \%)$. Twenty-three $(12.6 \%)$ were detected by the formal-ether sedimentation technique and $10(5.5 \%)$ by spontaneous sedimentation technique. Therefore, it was concluded that the soils in the city of Uberlandia are contaminated with eggs and larvae of geohelminths, enabling dissemination of illnesses among animals and human beings.

KEYWORDS: Geohelminths. Ascarididae. Soil. Epidemiology. Environmental contamination.

\section{INTRODUCTION}

Geohelminths are parasites which perform part of their life cycle in the soil, where eggs are embryonated and then larvae become viable, being in both stages able to infect their hosts, depending on the species ${ }^{1}$. Geohelminths have the development and survival dependent on the external environment. Climate factors such as proper humidity and temperature are critical for the embryonation of the eggs in the soil ${ }^{2}$. Thus, human infection is directly related to the degree of soil contamination and the type of soil use. In addition, regions with a large population of dogs, cats and pigs, especially stray ones, can have a higher prevalence of eggs, larvae-eggs and larvae of parasites in the environment. Among geohelminths, the Ascarididae family is important for human and animal health, mainly consisting of parasites of the genus Ascaris and Toxocara, which infective forms can be ingested by their hosts presenting asymptomatic or severe syndromes ${ }^{3}$.

Ascaris genus is represented mainly by Ascaris lumbricoides and A. suum, which L5 (adult) infests the small intestine of humans and pigs. Ascariasis is one of the most common parasitic infestations, with worldwide distribution facilitated by the resistance of their eggs to less favorable environmental conditions ${ }^{4,5}$. Human 
beings become infested by ingesting food, soil or water contaminated with Ascaris lumbricoides and/or Ascaris suum embryonated eggs, which hatch in the small intestine. Hands contaminated with eggs can be a source of infestation for breeders. Nail biting is also a risk factor in children and adults. The most severe infections of this parasite generally occur in children aging from 5 to 15 due to immune system maturation and changes in exposure to the parasite ${ }^{6}$. Parasite antigens activate the host's inflammatory response, inducing an eosinophilic infiltrate. The clinical features ranging from pneumonia, Loeffler's syndrome (due to migration of the larvae), to intestinal obstruction (due to adults), physical and cognitive impairment may occur, becoming more serious in reinfection ${ }^{4}$.

The presence of Ascaris sp. is observed in several epidemiological studies worldwide, in animal, human and ground $^{5,7-9}$. However, a prevalence reduction of this parasite has been observed. Researchers, such as Macchioni et al. ${ }^{9}$, reported significant reduction in prevalence of Ascaris lumbricoides, from $19 \%$ to $1.5 \%$, in relation to that observed 20 years ago in Bolivia, mainly due to the improvement of environmental and sanitary conditions in the region.

In the genus Toxocara, the species T. canis and T. cati live in the small intestine of canines and felines, respectively (definitive hosts). Other mammals, birds and humans infected with those roundworms are considered non-conventional hosts. These hosts accidentally ingest embryonated Toxocara eggs present in the soil, in contaminated water or food and in dog or cat fur ${ }^{10}$. The ingested eggs hatch in the small intestine and the larvae reach the bloodstream enabling migration to several organs such as liver, lungs, heart and brain, characterizing the larva migrans visceral syndrome (LMV) ${ }^{11}$.

In relation to the environmental contamination, studies analyzing roundworms in soil at different locations in Spain, Philippines and Poland pointed out the prevalence of $16.4 \%$, $31 \%$ and $22.2 \%$ to $41.18 \%$, respectively ${ }^{12,13}$. In squares and parks of Lavras, MG (2005), Pelotas, RS (2008), Maringa, PR (2011), Guarulhos, SP (2012) and Presidente Prudente, SP (2012) in Brazil, studies have shown varying prevalence of Toxocara sp. of $17.4 \%, 46 \%, 60.3 \%, 68.1 \%$ and $96 \%$, respectively ${ }^{14-18}$. In Uberlandia, Minas Gerais, $23.07 \%$ of the soil samples from squares were infected by Toxocara sp. ${ }^{19}$.

The diagnosis of roundworms in humans is performed by laboratory techniques (parasitological, enzyme immunoassays and molecular methods). Among the immunoassays, the most used detects specific antibodies raised to daily released excretory-secretory antigens (TES) by infecting larvae from their surface membranes ${ }^{20}$.

Optical microscopic analysis of the soil samples, such as centrifugal flotation, spontaneous sedimentation and centrifugal sedimentation have been used for roundworms. These techniques are suggested due to good diagnostic sensitivity, detecting light structures and heavy eggs ${ }^{21,22}$.

In this context, the aim of this study was to determine the prevalence and risk factors of Ascarididae and other geohelminths in the soil of different areas (clubs, parks, squares, gardens, schools) located in one city in the Southeast of Brazil.

\section{MATERIAL AND METHODS}

\section{Area and study site}

Uberlandia is located in the West macroregion (Triangulo Mineiro and Alto Paranaiba), in Minas Gerais State, Brazil. It is the second largest city in this Brazilian State, with an estimate of 676,613 inhabitants $^{23}$, a total area of $4.115,09 \mathrm{~km}^{2}$, situated in the latitude $1855^{\prime} 07 \mathrm{~S}$ and the longitude $4816^{\prime} 38 \mathrm{~W}$. It has an average temperature of $23{ }^{\circ} \mathrm{C}$ and rainfall from 1,500 to $1,600 \mathrm{~mm}$. The city is considered an example as for basic sanitation because it has $100 \%$ of treated water and $99 \%$ of the sewage collected by the Municipal Department of Water and Sewage (DEMAE).

This work was carried out in several neighborhoods in the urban area of the municipality in different areas of the city of Uberlandia, involving squares and public parks, clubs, gardens and kindergartens (EMEIs). All locations were present in all geographic regions.

Initially, survey of possible city collection sites (school recreation areas, squares and public parks, clubs and gardens) was carried out. They were listed based on information from the City Hall of Uberlandia, being included seven municipal parks, 15 clubs, 21 community and school gardens, 215 squares and 115 municipal schools. Among these municipal schools, 63 were EMEIs, and only 30 had recreation areas with sand, ground or grass.

After this survey, those in charge for the sites were contacted so that we could expose to them the study proposal to obtain their authorization for material collection after signature of the consent forms.

\section{Material collection}

Material collection occurred in 2014 and the collection periods were divided according to seasonality, being January to March considered as the rainy season, and June to August, the dry season.

Samples were collected using a PVC pipe measuring 5 $\mathrm{cm}$ in length $\mathrm{x} 6 \mathrm{~cm}$ in diameter. At the collection time, top soil was discarded, collecting the soil portion just below. Therefore, the PVC tube was inserted and five soil samples 
were collected at different points: one sample collected in four different points/sides, forming a quadrant, and a central sample. Soil types were classified according to their density and porosity. The collection procedure was repeated from the same spot during the rainy and dry seasons.

After collection, the samples were placed in plastic bags identified with the sample number, place and date, and transported in polystyrene boxes to the Parasitology Laboratory of the Federal University of Uberlandia (UFU) in order to be processed.

\section{Processing and microscopic examination}

In the Parasitology Laboratory of the Federal University of Uberlandia (UFU), samples were homogenized and $200 \mathrm{~g}$ of the soil were weighed and removed for analysis. Sample processing was performed immediately after collection and, when it was not possible, they were stored at $4{ }^{\circ} \mathrm{C}$ for up to $24 \mathrm{~h}$.

The parasitological methods used for the observation of Ascarididae eggs and other geohelminths in soil samples were the centrifugal sedimentation in formal-ether according to Ritchie ${ }^{24}$ and the spontaneous sedimentation ${ }^{25}$. For each technique, three slides per sample were made, and the analysis, in 40x magnification, was performed by two professionals trained to give a greater reliability to results.
The identification of the parasite forms was done based on atlas, scientific articles and teaching books.

\section{Statistical Analysis}

Agreement between diagnostic methods was established according to the KAPPA test from Bioestat 5.0 software, with a $95 \%$ confidence interval. For comparisons between two proportions, the Chi-square test $\left(\chi^{2}\right)$ was conducted and, when comparisons involved more than two proportions, a logistic regression was used, using Epi Info 3.5.1 software.

\section{Dissemination of results}

The results of the present study were sent to those in charge of the collection sites involved in the research, so that control measures could be taken in order to minimize soil contamination in these environments.

\section{RESULTS}

During the period from January to August 2014, 183 soil samples were collected in different locations of the city of Uberlandia. Eight of them (4.4\%) belonged to parks, $16(8.7 \%)$ to clubs, $76(41.5 \%)$ to squares, $23(12.6 \%)$ to gardens and $60(32.8 \%)$ to EMEIs (Figure 1).
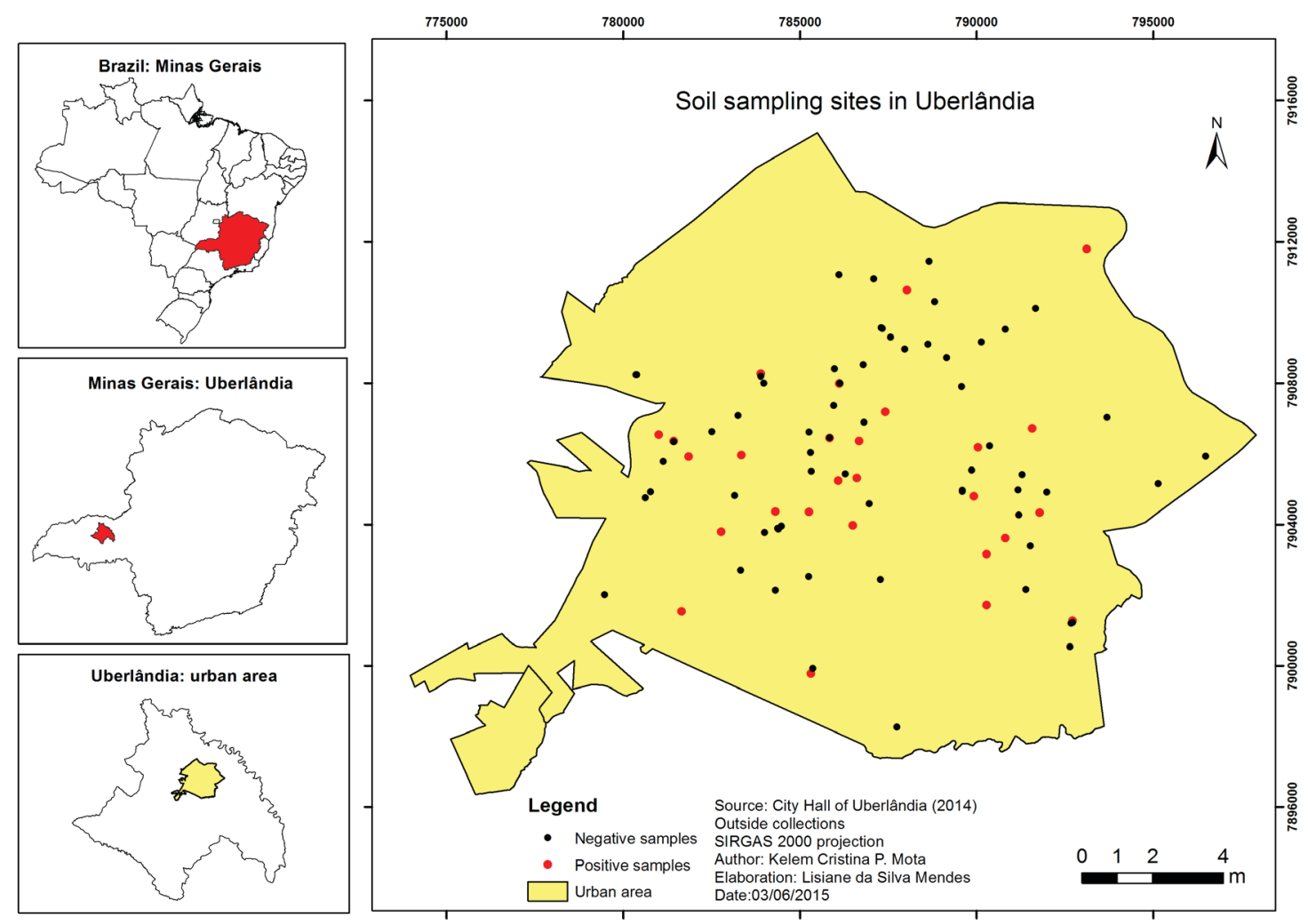

Figure 1 - Soil sampling sites in different areas of the city of Uberlandia, MG, Brazil, in the period from January to August 2014 
Table 1 - Distribution and soil contamination with Ascarididae eggs in different areas of the city of Uberlandia, MG, in the period January-August 2014

\begin{tabular}{lcc}
\hline Site & $\mathrm{N}$ & Positive $(\mathrm{n} / \%)$ \\
\hline Club & 16 & $5(17.8)$ \\
School & 60 & $5(17.8)$ \\
Garden & 23 & $8(28,6)$ \\
Park & 8 & $3(10.7)$ \\
Square & 76 & $7(25.0)$ \\
\hline Total & 183 & $28(100.0)$ \\
\hline
\end{tabular}

$\mathrm{n}=$ sample number; $\%$ percentage

Out of the total, 28 (15.3\%) were positive for Ascarids eggs, which has been found distributed in three parks (10.7\%), five clubs (17.8\%), seven squares (25.0\%), eight gardens $(28.6 \%)$ and five EMEIs (17.8\%) (Table 1).

During the analysis, eggs and larvae of other parasites, such as hookworms, Trichuris, Oxyurids and Strongyloides (Table 2) were observed.

The biggest positivity of parasites was observed in the South region of the city, corresponding to $25.1 \%$ of the samples, followed by the Western (22.4\%), East (19.7\%), North and Central regions (both with 16.4\%). However, from the logistic regression, it was possible to observe that there was no significant difference, indicating that none of the areas was considered a risk factor for the presence of parasites (Table 3).

According to seasonality, the soil had higher contamination in the rainy season $(26.2 \%)$ compared to the dry season $(12.5 \%)$, which is a significant difference $(\mathrm{p}<0.05)$.

In addition to these parameters, the positivity regarding the type of soil (sand, ground and grass) was analyzed. Of the 183 samples, 67 (36.6\%) were from sand, $61(33.3 \%)$ from grass and $55(30.1 \%)$ from ground. A higher positivity was observed in ground soil $(27.3 \%)$ with a significant

Table 2 - Parasitic forms found during the analysis of soil samples collected in different areas of the city of Uberlandia, MG, in the period from January to August 2014

\begin{tabular}{|c|c|c|c|c|c|}
\hline \multirow{2}{*}{ Evolutionary form } & \multirow{2}{*}{ Parasite species } & \multicolumn{2}{|c|}{ Diagnostic Methods } & \multicolumn{2}{|c|}{ Seasonality* } \\
\hline & & Hoffmann $n(\%)$ & Ritchie $\mathrm{n}(\%)$ & Rain & Drought \\
\hline & Ancylostoma sp & $5(11,90)$ & $2(4,76)$ & 7 & 0 \\
\hline \multirow[t]{3}{*}{ Eggs } & Trichuris sp. & 0 & $1(2,38)$ & 1 & 0 \\
\hline & Ascarididae & $10(5,43)$ & $23(12,5)$ & 23 & 5 \\
\hline & Ancylostoma sp & $10(23,80)$ & $6(14,28)$ & 11 & 10 \\
\hline \multirow[t]{2}{*}{ Larvae } & Oxyurida & $11(26,19)$ & $6(14,28)$ & 6 & 7 \\
\hline & Strongyloides sp. & 0 & $1(2,38)$ & 0 & 1 \\
\hline Total & & $36(19,7)$ & $39(21,3)$ & 48 & 23 \\
\hline
\end{tabular}

${ }^{*}$ According to the Climatology Laboratory of the Federal University of Uberlandia. $\mathrm{n}=$ sample number; \% percentage.

Table 3 - Distribution and soil contamination with Ascarids eggs in different soils and regions of the city of Uberlandia, MG, in the period from January to August 2014

\begin{tabular}{lccc}
\hline Variables & Positive \% & OR (Cl 95\%) & $p_{\text {-value }}^{*}$ \\
\hline Region & 25.1 & Reference & 0.76 \\
South & 22.4 & $0.85(0.28-2.52)$ & 0.30 \\
West & 19.7 & $0.51(0.14-1.83)$ & 0.75 \\
East & 16.4 & $0.82(0.25-2.74)$ & 0.27 \\
Center & 16.4 & $0.46(0.11-1.85)$ & \\
North & & & 0.64 \\
Soil type & 9 & Reference & $0.01^{*}$ \\
Sand & 11.5 & $1.32(0.42-4.16)$ & $3.81(1.36-10.65)$ \\
Grass & 27.3 & & \\
Ground & & & \\
\hline
\end{tabular}

${ }^{*} \mathrm{p} \leq 0.05 . \%=$ percentage; $\mathrm{Cl}=$ confidence interval, OR = Odds Ratio. 
difference when compared to sandy soil (9\%) ( $\mathrm{p}=0.01$ and $\mathrm{OR}=3.81$ ) (Table 3), which shows that ground soil is a risk factor for the presence of parasites, about four times more likely to be contaminated with parasitic developmental stages.

Out of the $28(15.3 \%)$ positive samples of Ascarids, $23(12.6 \%)$ were detected by centrifugal sedimentation in formal-ether and $10(5.5 \%)$ by spontaneous sedimentation (Table 2). There was no correlation between the parasitological methods (kappa $=0.343$ ), according to kappa, with $\mathrm{p}<0.05$ considered significant.

\section{DISCUSSION}

Tropical regions with favorable climate conditions for the development of the geohelminth lifecycle have soils susceptible to contamination by eggs and larvae of these parasites, through animals and humans defecation. The Uberlandia city falls within this regional context.

The results analyzed in this study observed reduction in positivity rate of Ascarids eggs in soil samples from Uberlandia when compared to surveys conducted by CostaCruz et al. ${ }^{19}$. High levels are observed in other regions of Brazil, such as $44.7 \%$ in three cities of Parana ${ }^{26}, 76.9 \%$ in Paranapanema - $\mathrm{SP}^{10}$ and $81 \%$ in Distrito Federal ${ }^{5}$. This difference in results may be related to the laboratory techniques, climate conditions (temperature, precipitation and humidity), as well as to the population's habits regarding personal hygiene and animal care.

The presence of species of Ascarididae family is reported in most studies of geohelminths, as shown by Paller and $\mathrm{Chavez}^{7}$, who reported that $31 \%$ of the soil samples were positive for some kind of geohelminth, with the highest rate presented by Toxocara sp (77\%) and Ascaris sp (11\%).

Besides the Ascarids eggs, in this study, a considerable number of evolutionary stages of the species of the family Ancylostomatidae was observed. These stages are often investigated in developed parasitological studies in Brazil, due to the clinical importance of cutaneous larva migrans, induced to zoonotic species of Ancylostoma ${ }^{15}$. This syndrome has been investigated in several States in Brazil, such as Sao Paulo, Parana and Rio Grande do Sul ${ }^{27,28,15}$.

The presence of several species of helminths in the environment appears to be common. Błaszkowska et al. ${ }^{29}$ observed Trichuris sp, Ascarididae and Ancylostoma spp. in soil samples in a city of Poland, according to the results of this study. Contamination is related to the presence of animals in places, origin of the fertilizer used in plantations and poor sanitation conditions.

The highest positivity found in the South sector of the city contradicts the social class of the region, since it is an area with higher economic class. It is important to highlight that this region presents more public recreational areas, and the population often walks with their pets on the streets and public squares. Therefore, the area becomes more susceptible to contamination by eggs and larvae of helminths transmitted by soil (STH).

Comparing soil contamination between the rainy and dry seasons, the results of this study corroborate the study by Castro et al. ${ }^{30}$, who observed a higher proportion of Ascarids and other geohelminths during the rainy season. Opposite results were observed by Tiyo et al. ${ }^{15}$ in Maringa, South of Brazil, who reported a higher prevalence of parasites in the soil in winter. However, it is noteworthy that the rainfall of collection periods in Uberlandia was lower than estimated in the previous years, which can directly influence the parasite survival in the soil. Another study relating seasonality to the presence of parasites in soil was developed by Blaszkowska et al. $^{29}$, who found no significant difference positivity of the samples over the seasons. However, the authors noted a higher concentration of eggs per samples in the rainy season, which clearly suggests the influence of climate factors on the development of STH.

In this study, the samples were obtained at the depth of $5 \mathrm{~cm}$ in order to get a higher amount of eggs. This collection technique is supported by a research conducted by Blaszkowska et al. ${ }^{29}$, who observed a greater amount of STH eggs in samples collected from the upper portion of the soil compared to the deeper layers.

The type of soil can influence the permanence and proliferation of evolutionary forms of parasites in the environment. Factors such as temperature, humidity, $\mathrm{pH}$, depth and soil texture can affect the embryonic development, viability, infectivity and eggs size ${ }^{31}$. The highest positivity in ground soils observed in this study is supported by the study by Paller and $\mathrm{Chavez}^{7}$, who found a higher prevalence in low density soil (38\%), followed by clay soil.

The observation of eggs in conventional parasitological examinations may be dependent on the chosen laboratory technique. When comparing the techniques used in this research, it was observed that the formal-ether technique presented greater sensitivity. This result differed from that observed by Silva et al. ${ }^{5}$, who detected higher proportion of eggs in the spontaneous sedimentation technique. The results of the parasitological diagnosis methods may be influenced by the appearance of the slides which, when prepared with material obtained from the spontaneous sedimentation presented detritus, making it difficult to analyze the material.

The soil of studied areas presenting considerable rates of Ascarids and hookworm eggs may contribute to the spread of diseases in animals and humans. Ground soils are more 
prone to contamination by geohelminth eggs whereas the rain influences the presence and survival of eggs of these parasites in the soil. For parasitological analysis of soil, formal-ether technique becomes more sensitive due to a better appearance of the slides.

In addition to the parameters analyzed and discussed in this study, Blaszkowska et al. ${ }^{29}$ also observed that sites with free access of dogs and cats are more vulnerable to contamination by STH eggs. This factor is reported because these animals are often infested by zoonotic species, becoming potential reservoirs of important parasitic diseases in public health.

According to the results and risk factors described, it is observed that evolutionary forms of Ascarids are considerably contaminating the soil of several localities of the city. In addition, the zoonotic potential of these parasites should be highlighted, as an alarming situation for the animal and human population. Requiring interventions in the local community to intensify control measures aimed at reducing soil contamination rates in the region. Further clarification is needed on basic sanitation, especially in children, and hygienic measures in relation to pets, especially regarding the use of antiparasitic drugs. Thus, the present study promotes future research that emphasizes these parasites in regions near the city of Uberlandia, MG.

\section{ACKNOWLEDGMENTS}

We would like to thank the Coordenação de Aperfeiçoamento de Pessoal de Nivel Superior (CAPES) for financial support of research. We thank the English reviewer Jussara Carneiro Úngari, as well as Lisiane da Silva Mendes for her assistance in the map elaboration.

\section{REFERENCES}

1. Rocha S, Pinto RM, Floriano AP, Teixeira LH, Bassili B, Martinez A, et al. Environmental analyses of the parasitic profile found in the sandy soil from the Santos municipality beaches, SP, Brazil. Rev Inst Med Trop Sao Paulo. 2011;53:277-81.

2. Brooker S, Clements AC, Bundy DA. Global epidemiology, ecology and control of soil-transmitted helminth infections. Adv Parasitol. 2006;62:221-61.

3. Queiroz ML, Viel TA, Papa CH, Lescano SA, Chieffi PP. Behavioral changes in Rattus norvegicus coinfected by Toxocara canis and Toxoplasma gondii. Rev Inst Med Trop Sao Paulo. 2013;55:51-3.

4. Bethony J, Brooker S, Albonico M, Geiger SM, Loukas A, Diemert $\mathrm{D}$, et al. Soil-transmitted helminth infections: Ascariasis, trichuriasis, and hookworm. Lancet. 2006;367:1521-32.

5. Silva SR, Maldonade IR, Ginani VC, Lima SA, Mendes VS,
Azevedo ML, et al. Detection of intestinal parasites on fieldgrown strawberries in the Federal District of Brazil. Rev Soc Bras Med Trop. 2014;47:801-5.

6. Galvani AP. Age-dependent epidemiological patterns and strain diversity in helminth parasites. J Parasitol. 2005;91:24-30.

7. Paller VG, Chavez ER. Toxocara (Nematoda: Ascaridida) and other soil-transmitted Helminth eggs contaminating soils in selected urban and rural areas in the Philippine. ScientificWorldJournal. 2014;2014:386232.

8. Schär F, Inpankaew T, Traub RJ, Khieu V, Dalsgaard A, Chimnoi $\mathrm{W}$, et al. The prevalence and diversity of intestinal parasitic infections in humans and domestic animals in a rural Cambodian village. Parasitol Int. 2014;63:597-603.

9. Macchioni F, Segundo H, Gabrielli S, Totino V, Gonzales PR, Salazar E, et al. Dramatic decrease in prevalence of soiltransmitted helminthiasis and new insights into intestinal protozoa in children living in the Chaco region, Bolivia. Am J Trop Med Hyg. 2015;92:794-6.

10. Santarém VA, Dias AP, Felix A, Rodenas RS, Silva AV. Contaminação por ovos de Toxocara spp. em praças públicas das regiões central e periurbana de Mirante do Paranapanema, São Paulo, Brasil. Vet Zootec. 2010;17:47-53.

11. Hotez PJ, Wilkins PP. Toxocariasis: America's most common neglected infection of poverty and a helminthiasis of global importance? PLoS Negl Trop Dis. 2009;3:e400.

12. Borecka A, Gawor J. Modification of gDNA extraction from soil for PCR designed for the routine examination of soil samples contaminated with Toxocara spp. eggs. J Helminthol. 2008;82:119-22.

13. Wiśniewska-Ligier M., Woźniakowska-Gesicka T, SobolewskaDryjańska J, Markiewicz-Jóźwiak A, Wieczorek M. Analysis of the course and treatment of toxocariasis in children - a long-term observation. Parasitol Res. 2012;110:2363-71.

14. Guimarães AM, Alves EG, Rezende GF, Rodrigues MC. Ovos de Toxocara sp. e larvas de Ancylostoma sp. em praça pública de Lavras, MG. Rev Saude Publica. 2005;39:293-5.

15. Tiyo R, Guedes TA, Falavigna DL, Falavigna-Guilherme AL. Seasonal contamination of public squares and lawns by parasites with zoonotic potential in southern Brazil. J Helminthol. 2008;82:1-6.

16. Gallina T, Silva MA, Castro LL, Wendt EW, Villela MM, Berne ME. Presence of eggs of Toxocara spp. and hookworms in a student environment in Rio Grande do Sul, Brazil. Rev Bras Parasitol Vet. 2011;20:176-7.

17. Marques JP, Guimarães CR, Boas AV, Carnaúba PU, Moraes JD. Contamination of public parks and squares from Guarulhos (São Paulo State, Brazil) by Toxocara spp. and Ancylostoma spp. Rev Inst Med Trop São Paulo. 2012;54:267-71.

18. Santarém VA, Pereira VC, Alegre BC. Contamination of public parks in Presidente Prudente (São Paulo, Brazil) by Toxocara spp. eggs. Rev Bras Parasitol Vet. 2012;21:323-5. 
19. Costa-Cruz JM, Nunes RS, Buso AG. Presença de ovos de Toxocara spp em praças públicas da cidade de Uberlândia, Minas Gerais, Brasil. Rev Inst Med Trop São Paulo. 1994;36:39-42.

20. Cortés NN, Núñez CR, Guiliana BG, García PA, Cárdenas RH. Presence of anti-Toxocara canis antibodies and risk factors in children from the Amecameca and Chalco regions of México. BMC Pediatr. 2015;15:65.

21. Faust EC, Sawitz W, Tobie J, Odom V, Peres C, Lincicome DR. Comparative efficiency of various technics for the diagnosis of Protozoa and helminths in feces. J Parasitol. 1939;25:241-62.

22. Dryden MW, Payne PA, Ridley R, Smith V. Comparison of common fecal flotation techniques for the recovery of parasite eggs and oocysts. Vet Ther. 2005;6:15-28.

23. Instituto Brasileiro de Geografia e Estatística. Brasil/Minas Gerais/Uberlândia. [cited 2018 Feb 16]. Available from: https:// cidades.ibge.gov.br/brasil/mg/uberlandia/panorama

24. Ritchie LS. An ether sedimentation technique for routine stool examination. Bull U S Army Med Dep. 1948;8:326.

25. Hoffmann WA, Pons JA, Janer JL. The sedimentationconcentration method in Schistosomiasis mansoni. Puerto Rico J Public Health. 1934;9:283-91.

26. Mattia S, Colli CM, Adami CM, Guilherme GF, Nishi L,
Rubinsky-Elefant G, et al. Seroprevalence of Toxocara infection in children and environmental contamination of urban areas in Parana State, Brazil. J Helminthol. 2012;86:440-5.

27. Scaini CJ, Toledo RN, Lovatel R, Dionello MA, Gatti FA, Susin L, et al. Contaminação ambiental por ovos e larvas de helmintos em fezes de cães na área central do Balneário Cassino, Rio Grande do Sul. Rev Soc Bras Med Trop. 2003;36:617-9.

28. Santarém VA, Giuffrida R, Zanin GA. Larva migrans cutânea: ocorrência de casos humanos e identificação de larvas de Ancylostoma spp em parque público do município de Taciba, São Paulo. Rev Soc Bras de Med Trop. 2004;37:179-81.

29. Błaszkowska J, Góralska K, Wójcik A, Kurnatowski P, Szwabe K. Presence of Toxocara spp. eggs in children's recreation areas with varying degrees of access for animals. Ann Agric Environ Med. 2015;22:23-27.

30. Castro JR, Souza MA, Salaberry SR, Naves JH, Guimarães EC, Lima-Ribeiro AM. Leptospirose canina relacionada à sazonalidade no município de Uberlândia, MG. Cienc Anim. 2011;21:77-86

31. Amadi EC, Uttah EC. Impact of physico-chemical factors of contaminated foci on the survival of geohelminths in Abua Communities, Niger Delta Nigeria. J Appl Sci Environ Manage. 2010;14:117-21. 